\title{
4 Long-Range Atmospheric Transport and Local Pollution 5 Sources on PAH Concentrations in a South European 6 Urban Area. Fulfilling of the European Directive
}

\author{
M. S. Callén • M. T. de la Cruz • J. M. López • \\ R. Murillo • M. V. Navarro • A. M. Mastral
}

Received: 16 August 2007 / Accepted: 9 December 2007

(C) Springer Science + Business Media B.V. 2007

Abstract A 12 months study on urban atmospheric concentrations of polycyclic aromatic hydrocarbons $(\mathrm{PAH})$ contained in the particulate matter with an aerodynamic diameter less than or equal to 10 microns (PM10) was carried out in Zaragoza (Spain) from July 12th, 2001 to July 26th, 2002 by using a high-volume air sampler able to collect the PAH supported on a Teflon-coated fibre glass filter. Samples were analysed by using Gas Chromatography Mass Spectrometry (GC-MS/MS). PAH of high molecular weight, indeno [1,2,3-cd]pyrene (IcdP), benzo[g,h,i]perylene (BghiP) and coronene $(\mathrm{Co})$ were the most abundant compounds. The concentrations of benz[a]pyrene equivalent carcinogenic power (BaP-eq) showed a mean value of $0.7 \mathrm{ng} / \mathrm{m}^{3}$ with $22.5 \%$ of the samples exceeding the $1.0 \mathrm{ng} / \mathrm{m}^{3}$ guide value established by the European Directive. These episodes were mainly produced during cold season. Regarding meteorological variables, a positive effect of the prevalent wind "cierzo" (NW direction) over the Zaragoza city was confirmed from the environmental point of view. The $\mathrm{NE}, \mathrm{E}$ and $\mathrm{S}$ directions, corresponding to highway and industrial areas were the directions showing the high PAH atmospheric concentrations. Despite the

M. S. Callén $(\bowtie) \cdot M$. T. de la Cruz • J. M. López

R. Murillo $\cdot$ M. V. Navarro - A. M. Mastral

Instituto de Carboquímica (CSIC),

Miguel Luesma Castán, 4,

50018, Zaragoza, Spain

e-mail: marisol@icb.csic.es proximity of a high-level traffic highway, stationary sources related to industry were the dominant source of PAH in the sampled area. Vehicular emissions and natural gas home heating also contributed to PAH concentrations. The predominance of local pollution sources versus long-range transport on PAH concentrations was shown. However, the contribution of long-range transport of anthropogenic origin from other European areas was reflected for specific dates on PAH concentrations and PM10 levels.

Keywords Air pollution.

Long-range atmospheric transport · PAH · PM10 .

Pollution sources

\section{Introduction}

The presence of atmospheric Polycyclic Aromatic Hydrocarbons (PAH) are mainly due to human activities (Mastral and Callén 2000). However, in South European countries due to their dry and hot climatology, the natural sources, e.g. higher forest fires incidence, can increase the atmospheric PAH levels.

The vapour pressure of some PAH makes them highly mobile throughout the environment. Furthermore, deposition and re-volatilisation allow distribution between air, soil and water bodies. In this way, a proportion of PAH is subject to long-range atmospheric transport making them a transboundary environmental problem (Halsall et al. 2001; Prevedouros 
64 et al. 2004). In particular, the South European 65 countries, mainly affected by the transport of mineral 66 dust from the African continent, could be also 67

107 to know the sources producing these pollutants and 108 how these PAH behave in the atmosphere once they 109 are released, so that it is possible to act to control 110 them when necessary.

111 In this paper, PAH concentrations in an urban 112 atmosphere of Zaragoza city were determined paying special attention to the most carcinogenic PAH, the fulfilling of the present Directive regarding PAH and the pollution sources producing these compounds.

\section{Experimental}

\subsection{Sampling Program}

The study was performed in the city of Zaragoza (650,592 habitants) located in the Northeast of Spain $\left(41^{\circ} 39^{\prime} 49.38^{\prime \prime} \mathrm{N} ; 0^{\circ} 53^{\prime} 16.68^{\prime \prime} \mathrm{W}\right)$ and previously described in another article (López et al. 2005). This city is also characterized by a special kind of wind called "cierzo" which comes from the Moncayo Mountain, North-West direction.

The sampling was performed in an urban area where sources of anthropogenic emissions surrounding the sampling site included a high level traffic highway (A-2; 38695 vehicles/day in 2006) and several industrial parks related to medium and small enterprises (Cogullada: 130 enterprises (28\% metal sector; 30\% distribution sector); Malpica: 300 enterprises $(33 \%$ metal sector; chemical, plastic, commerce); Argualas: 34 enterprises (37\% commerce and distribution); Miguel Servet: (varied industry; 36\% commerce and distribution; footwear, wood, textil, metal); S. Valero: 80 enterprises (50\% iron and steel industry; wood, distribution); El Pilar: 26 enterprises (35\% commerce and distribution); Molino El Pilar: 117 enterprises (13\% metal; 39\% commerce and distribution); La Cartuja: 25 enterprises (45\% metal sector; $25 \%$ electronic; chemistry, plastic, paper, etc); Mercazaragoza: 112 enterprises (agroalimentary industry, slaughterhouse)), two paper fabrics and two water-treatment systems (see Fig. 1).

Samples were collected every 2 weeks from July 12th, 2001 to July 26th, 2002 on weekdays. More intensive sampling dates: $11,12,13,14$ and 15th March 2002, 18, 19, 20 and 21st June 2002, 22, 23, 24 and 26th July 2002 corresponding to winter, spring and summer seasons were carried out collecting a total of 41 samples. A GUV-15H Graseby Andersen High-Volume sampler with volumetric flow controlled system provided with a PM10 cut off inlet at $10 \mu \mathrm{m}$ and located $3.5 \mathrm{~m}$ from the ground was used to collect particulate phase in a PTFE-coated, glass-fibre filters $(0.6 \mu \mathrm{m}$ pore size; $20.5 \times 25.5 \mathrm{~cm}$, Pall GelmanSciences). Sampling time was $24 \mathrm{~h}$, yielding 
Water Air Soil Pollut

Fig. 1 Localization of the sampling place in Zaragoza city

158 sample volumes among 1,200 and $1,700 \mathrm{~m}^{3}$. Before 159 the sampling, filters were cleaned by Soxhlet extrac160 tion for $24 \mathrm{~h}$ with dichloromethane (DCM) and kept 161 in desiccators before and after sampling. Filters were 162 also weighted before and after the sampling using a 163 microbalance to obtain the particulate mass. After 164 sampling, filters were wrapped in aluminium foil 165 previously rinsed with hexane and stored in a freezer 166 at $-20^{\circ} \mathrm{C}$ until analysis.

\section{2.2 Extraction and Analyses}

168 Particulate matter contained in the filters was 169 extracted by Soxhlet during $18 \mathrm{~h}$ with DCM after 170 the addition of deuterated-PAH surrogate standards 171 containing the following PAH: acenaphthene- $\mathrm{d}_{10}$ $172\left(\right.$ Ace- $\left.\mathrm{d}_{10}\right)$, anthracene- $\mathrm{d}_{10}\left(\right.$ An- $\left.\mathrm{d}_{10}\right)$, benzo[a]pyrene$173 \mathrm{~d}_{12}\left(\mathrm{BaP}_{-12}\right)$ and benzo[g,h,i]perylene- $\mathrm{d}_{12}$ (BghiP$174 \mathrm{~d}_{12}$ ). Extracts were then concentrated in a rotary 175 evaporator followed by re-concentration under a 176 gentle stream of nitrogen, solvent exchanged into 177 hexane and cleaned using solid-liquid chromatogra178 phy on silica gel prior to PAH analysis. A known 179 amount of p-terphenyl was added to the sample 180 previous to the analysis by gas chromatography in 181 order to calculate the deuterated PAH's recovery.
PAH quantification was performed using the internal standard method relative to the closest eluting PAH surrogate.

All analyses were carried out on a Varian GC 3800 gas chromatograph coupled to a Saturn 2200 mass spectrometer detector (electron ionization mode and ion-trap analyser with mass/mass option) with GC capillary column $(60 \mathrm{~m} \times 0.25 \mathrm{~mm} \times 0.25 \mu \mathrm{m})$ working in MS-MS mode. 1 microlitre of sample was injected in splitless-mode.

The oven temperature was programmed as follows: $60^{\circ} \mathrm{C}$ isotherm for $1 \mathrm{~min}, 10^{\circ} / \mathrm{min}$ till $300^{\circ} \mathrm{C}$ and isotherm for $20 \mathrm{~min}$. The injector was kept at the following conditions: $60^{\circ} \mathrm{C}$ for $0.5 \mathrm{~min}, 100^{\circ} \mathrm{C} / \mathrm{min}$ till $300^{\circ} \mathrm{C}$ and isotherm for $15 \mathrm{~min}$. Helium was used as carrier gas at a constant flow of $1 \mathrm{ml} / \mathrm{min}$ and transfer line was heated at $280^{\circ} \mathrm{C}$. In all cases, $1 \mu \mathrm{l}$ of sample was injected in splitless mode (1/50, split valve closed for $3.5 \mathrm{~min})$. The ion trap mass spectrometer was operated in electron ionization (EI) mode and the filament emission current was $80-90 \mu \mathrm{A}$. The mass conditions were as follows: electron impact ionization voltage $70 \mathrm{eV}$; scan time $0.5 \mathrm{~s} / \mathrm{scan}$; scanned mass range: $40-650 \mathrm{~m} / \mathrm{z}$. The MS-MS process was conducted by collision induced dissociation (CID) with resonant excitation. 
208 The compounds quantified during sampling, ac209 cording to their elution orders, were: naphthalene $(\mathrm{Np}$, $210 \mathrm{~m} / \mathrm{z}$ 102), acenaphthylene (Acy, m/z 150), acenaph211 thene (Ace, $\mathrm{m} / \mathrm{z} 151$ ), fluorene ( $\mathrm{Fl}, \mathrm{m} / \mathrm{z} 163)$, phenan212 threne (Phe, $\mathrm{m} / \mathrm{z}$ 152), anthracene (An, m/z 152), 2+2/ 213 4-methylphenanthrene (2+2/4MePhe, m/z 189), 214 9-methylphenanthrene (9MePhe, m/z 189), 1-meth215 ylphenanthrene (1MePhe, $\mathrm{m} / \mathrm{z} 189$ ), 2,5-/2,7-/4, 216 5-dimethylphenanthrene (Dimephe, $\mathrm{m} / \mathrm{z}$ 191), fluo217 ranthene (Fth, m/z 200), pyrene (Py, m/z 200), benz 218 [a] anthracene $(\mathrm{BaA}, \mathrm{m} / \mathrm{z} 226)$, chrysene (Chry, $\mathrm{m} / \mathrm{z}$ 219 226), benzo[b]fluoranthene (BbF, $\mathrm{m} / \mathrm{z} 250)$, benzo[k] 220 fluoranthene $(\mathrm{BkF}, \mathrm{m} / \mathrm{z} 250)$, benzo[e]pyrene (BeP, $221 \mathrm{~m} / \mathrm{z} \mathrm{250}$ ), benzo[a]pyrene (BaP, m/z 250), indeno 222 [1,2,3-cd]pyrene (IcdP, m/z 274), dibenzo[a,h]anthra223 cene (DahA, m/z 276), benzo[g,h,i]perylene (BghiP, $224 \mathrm{~m} / \mathrm{z}$ 274) and coronene (Co, m/z 298).

225 The meteorological parameters of the sampling 226 place for each sampling date including temperature, 227 relative humidity, rainfall, irradiation, wind direction 228 and speed were provided by the Spanish National 229 Institute of Meteorology.

\subsection{Quality Control and Quality Assurance}

231 Analyte losses during the analytical procedure were eval232 uated by adding a known amount of deuterated PAH 233 surrogate standards, above mentioned, before the Soxhlet extraction. According to the results obtained, the concentrations regarding the most volatile $\mathrm{PAH}, \mathrm{Np}$, Acy, Ace and Fl could not be accurately identified by this method due to the low recovery, poor reproducibility of their results and for staying below the quantification limit. In this way, these four PAH were not considered in the interpretation of results. IcdP and DahA were quantified together due to the problem of discerning both peaks in some samples with the majority contribution of IcdP. Regarding the rest of PAH, no corrections were applied.

Limits of detection for individual compounds were defined by multiplying by 3 and 10 the standard deviation of the blank filters, respectively, with the lowest detection limit for BkF: $0.001 \mathrm{ng} / \mathrm{m}^{3}$ and the highest for IcdP: $0.036 \mathrm{ng} / \mathrm{m}^{3}$ (Table 1).

In order to check the analytical accuracy and precision, analyses of an appropriate standard reference material (SRM 1944, Waterway sediment) of National Institute of Standards and Technology (NIST) were analysed. Measured values were comparable to certified values with a precision between $0.2 \%$ (for $\mathrm{BkF}$ ) and $22 \%$ (for $\mathrm{BaA}$ ) for all compounds.

\subsection{Statistical Tools}

All statistical analyses, including Pearson correlation coefficients and Principal Component Analysis (PCA), were conducted using SPSS for Windows
Table 1 Detection limit $\left(\mathrm{ng} / \mathrm{m}^{3}\right)$, minimum, maximum, mean concentration and standard deviation $\left(\mathrm{ng} / \mathrm{m}^{3}\right)$ of the different PAH sampled in Zaragoza during July 2001-July 2002

N.D Not detected

\begin{tabular}{llllll}
\hline & $\begin{array}{l}\text { Detection } \\
\text { limit }\end{array}$ & $\begin{array}{l}\text { Minimum } \\
\text { concentration }\end{array}$ & $\begin{array}{l}\text { Maximum } \\
\text { concentration }\end{array}$ & $\begin{array}{l}\text { Mean } \\
\text { concentration }\end{array}$ & $\begin{array}{l}\text { Standard } \\
\text { deviation }\end{array}$ \\
\hline Phe & 0.034 & N.D & 2.67 & 0.32 & 0.56 \\
An & 0.021 & N.D & 0.68 & 0.09 & 0.17 \\
$2+2 / 4 \mathrm{MePh}$ & 0.012 & N.D & 1.33 & 0.19 & 0.27 \\
9MePhe & 0.003 & N.D & 0.45 & 0.06 & 0.10 \\
1MePhe & 0.011 & N.D & 0.66 & 0.10 & 0.16 \\
Dimephe & 0.009 & N.D & 2.25 & 0.21 & 0.39 \\
Fth & 0.015 & N.D & 6.10 & 0.71 & 1.08 \\
Py & 0.013 & 0.05 & 6.35 & 0.72 & 1.09 \\
BaA & 0.002 & 0.02 & 4.33 & 0.59 & 0.79 \\
Chry & 0.002 & 0.03 & 4.35 & 0.83 & 0.99 \\
BbF & 0.004 & 0.06 & 4.51 & 0.68 & 0.89 \\
BkF & 0.001 & N.D & 1.54 & 0.26 & 0.34 \\
BeP & 0.002 & 0.05 & 2.71 & 0.50 & 0.58 \\
BaP & 0.002 & 0.03 & 2.11 & 0.45 & 0.51 \\
IcdP+DahA & 0.036 & N.D & 3.38 & 0.99 & 1.00 \\
BghiP & 0.003 & 0.05 & 3.32 & 0.97 & 0.86 \\
Co & 0.002 & 0.05 & 4.81 & 1.09 & 1.15 \\
Total PAH & & 0.40 & 30.22 & 8.77 & 7.90 \\
& & & & & \\
\hline
\end{tabular}

257

258

259

t1.1

t1. 2

t1.3

t1. 4

t 1.5

t1.6

t1.7

t1.8

t1.9

t1.10

t1.11

t1.12

t1.13

t1.14

t1.15

t1.16

t1.17

t1.18

t1.19 
Water Air Soil Pollut

260 version 12.0. These statistical tools were applied to 261 the PAH variables (Phe, An, 2+2/4MePhe, 9MePhe, 262 1MePhe, Dimephe, Fth, Py, BaA, Chry, BbF, BkF, $263 \mathrm{BeP}, \mathrm{BaP}, \mathrm{IcdP}+\mathrm{DahA}$, BghiP, Co), total PAH, PM10 264 and the meteorological data (average temperature, 265 relative humidity, rainfall, irradiation, wind direction 266 and wind speed) for all the air samples.

\section{2.5 Long-Range Transport}

268 The long-range atmospheric transport was deduced by 269 determining isentropic backward air trajectories using 270 the HYSPLIT4 (Hybrid Single-Particle Lagrangian 271 Integrated Trajectory) model with FNL meteorologi272 cal input (HYSPLIT 4, 1997). In addition, Earth Probe 273 TOMS (Total Ozone Mapping Spectrometer) aerosol 274 index maps from Earth Probe NASA (http://toms.gsfc. 275 nasa.gov/eptoms/ep_v8.html), which measure the rela276 tive amount of aerosols, solid or liquid particles sus277 pended in the atmosphere, SeaWiFS-NASA satellite 278 images (http://www.nrlmry.navy.mil/aerosol/) to detect 279 dust plumes and synoptic charts of pressure at sea level 280 (http://www.arl.noaa.gov/ready/amet.html), which show 281 the weather conditions of different areas at a particular 282 time, were also useful to support the interpretations 283 from the NOAA Air Data Resources Laboratory.

\section{Results and Discussion}

285 3.1 PAH Concentration Levels

286 Daily PM10 levels and total PAH concentrations for 287 each sampling date are shown in Fig. 2. It is observed that there are $34 \%$ of the samples in which the PM10 exceeded the daily air quality $\left(50 \mu \mathrm{g} / \mathrm{m}^{3}\right)$. In addition, the average $\left(43.2 \mu \mathrm{g} / \mathrm{m}^{3}\right)$ also exceeded the yearly average $\left(40 \mu \mathrm{g} / \mathrm{m}^{3}\right)$ allowed by the European legislation (Directive 1999/30/EC).

Minimum, maximum and mean concentrations for each PAH identified in the PM10 are shown in Table 1 obtaining a mean total PAH concentration for the $18 \mathrm{PAH}$ in Zaragoza of $8.77 \mathrm{ng} / \mathrm{m}^{3}$. The concentrations of the studied PAH at this sampling site were compared with results obtained in studies conducted at various urban centres.

Similar mean total PAH values were found for sampling performed in Athens, in particular in an urban localization characterized by dense vehicular traffic and commercial activity $\left(8.54 \mathrm{ng} / \mathrm{m}^{3}\right)$ and in a mixed urban-industrial location in a highly industrialized area close to a highway $\left(7.93 \mathrm{ng} / \mathrm{m}^{3}\right)$ during May 2001-June 2002 (Mantis et al. 2005).

Slightly lower particulate phase PAH concentrations, with the exception of $\mathrm{Co}$, were also obtained at an urban site in Birmingham, UK, during 1992-1993 (Smith et al. 1996). Also in Birmingham, similar mean values were found for $\mathrm{Ph}, \mathrm{Co}$ and $\mathrm{BaA}$ during a campaign performed in 1997 at a heavily trafficked city centre (Lim et al. 1999).

Regarding sampling performed in this work, the highest contribution to the total of PAH corresponded to PAH with four or more aromatic rings, the most toxic and carcinogenic PAH. The total mass was dominated by PAH like BghiP, IcdP and Co (11.1, 11.3 and 12.4\%) revealing the importance of traffic to PAH concentrations (Nielsen 1996).
Fig. 2 Levels of PM10 $\left(\mu \mathrm{g} / \mathrm{m}^{3}\right)$ and PAH $\left(\mathrm{ng} / \mathrm{m}^{3}\right)$ for the different sampling dates

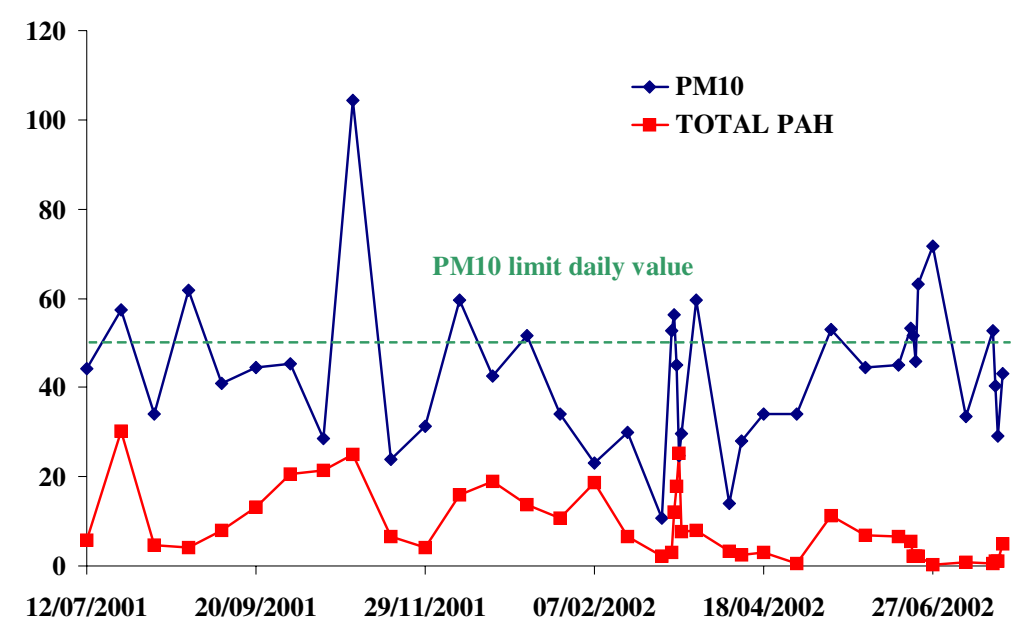


337 One of the most interesting PAH to study due to 338 its carcinogenic character and to the target value of $3391.0 \mathrm{ng} / \mathrm{m}^{3}$ established by the Directive 2004/107/CE 340 is the $\mathrm{BaP}$. The $\mathrm{BaP}$, showed variations between $3410.03 \mathrm{ng} / \mathrm{m}^{3}$, the lowest value and $2.11 \mathrm{ng} / \mathrm{m}^{3}$, the 342 highest value with $14.6 \%$ of the samples exceeding $3431.0 \mathrm{ng} / \mathrm{m}^{3}$ and with a mean value of $0.45 \mathrm{ng} / \mathrm{m}^{3}$ 344 (Table 1). Comparing with other studies performed in 345 other European countries, this mean value was slightly 346 lower than the one found in a urban location in Atenas, $3470.56 \mathrm{ng} / \mathrm{m}^{3}$ (Mantis et al. 2005), and very similar to the 348 one found in Birmingham, $0.48 \mathrm{ng} / \mathrm{m}^{3}$ (Smith et al. 349 1996) during 1992. Other samplings performed in Italy 350 in previous years showed values of $\mathrm{BaP}$ of 1.56 and $3511.72 \mathrm{ng} / \mathrm{m}^{3}$ respectively, in traffic areas of Rome and 352 Naples in 1994 and 1996-1997 (Cecinato et al. 1999; 353 Caricchia et al. 1999). Considering results obtained in 354 no European countries, similar $\mathrm{BaP}$ values were found 355 in another sampling station with heavy traffic in Porto 356 Alegre, Brazil, $0.52 \mathrm{ng} / \mathrm{m}^{3}$ (Dallarosa et al. 2005a).

357 Comparing with other Spanish cities, mean BaP 358 values of $0.547 \mathrm{ng} / \mathrm{m}^{3}$ were found in the PM10 during 359 2000-2001 in Seville (Gutiérrez-Dabán et al. 2005). 360 However, the comparisons should be done with 361 caution due to the unique characteristics of each 362 sampling site, the different time of the year to conduct 363 the sampling and differing procedures for sample 364 collection, clean-up and analysis.

365 Due to not only $\mathrm{BaP}$ is carcinogenic and because 366 the Directive 2004/107/CE also considers other relevant PAH (BaA, BfF, BjF, BkF, IcdP, DahA) in addition to $\mathrm{BaP}$, it was also interesting to know the BaP equivalent (BaP-eq) (Fig. 3). BaPE is calculated according to the following formula:

$\mathrm{BaP}-\mathrm{eq}\left(\mathrm{ng} / \mathrm{m}^{3}\right)=\sum \mathrm{FTe}_{\mathrm{i}} \mathrm{PAH}_{\mathrm{i}}$

Where $\mathrm{PAH}_{\mathrm{i}}$ is the concentration of each individual PAH (Phe, An, Fth, Chry, BaA, BbF, BkF, BeP, BaP, IcdP + DahA, BghiP) and $\mathrm{FTE}_{\mathrm{i}}$ the toxic equivalent factor for each PAH. In this work, it has been used the FTE proposed by Larsen and Larsen (1998) as they are the last ones published and reviewed.

It is worth saying that as IcdP was quantified together with DahA it is possible that the BaP-eq values are underestimated. Nevertheless, in most of the samples the DahA was negligible.

In this way, a better carcinogenicity parameter related to the whole PAH fraction instead of the $\mathrm{BaP}$ was achieved, especially if it is taken into account that $\mathrm{BaP}$ can easily photodegrade with light or oxidants and considering that with the Directive 2004/107/EC, not only $\mathrm{BaP}$ will be submitted to legislation.

The mean value of BaP-eq was $0.7 \mathrm{ng} / \mathrm{m}^{3}$ with BaP-eq exceeding $1 \mathrm{ng} / \mathrm{m}^{3}$ in nine cases which represents the $22.5 \%$ of the samples. This mean value was lower than the ones found for downtown Athens in $1996\left(1.6 \mathrm{ng} / \mathrm{m}^{3}\right)$ (Marino et al. 2000) and downtown Algiers $\left(3.4 \mathrm{ng} / \mathrm{m}^{3}\right)$ (Yassaa et al. 2001).
Fig. 3 BaP-eq and average BaP concentrations $\left(\mathrm{ng} / \mathrm{m}^{3}\right)$ for the different sampling dates in Zaragoza $\left(1 \mathrm{ng} / \mathrm{m}^{3}\right.$ target value for $\mathrm{BaP}$ according to Directive 2004/107/EC)

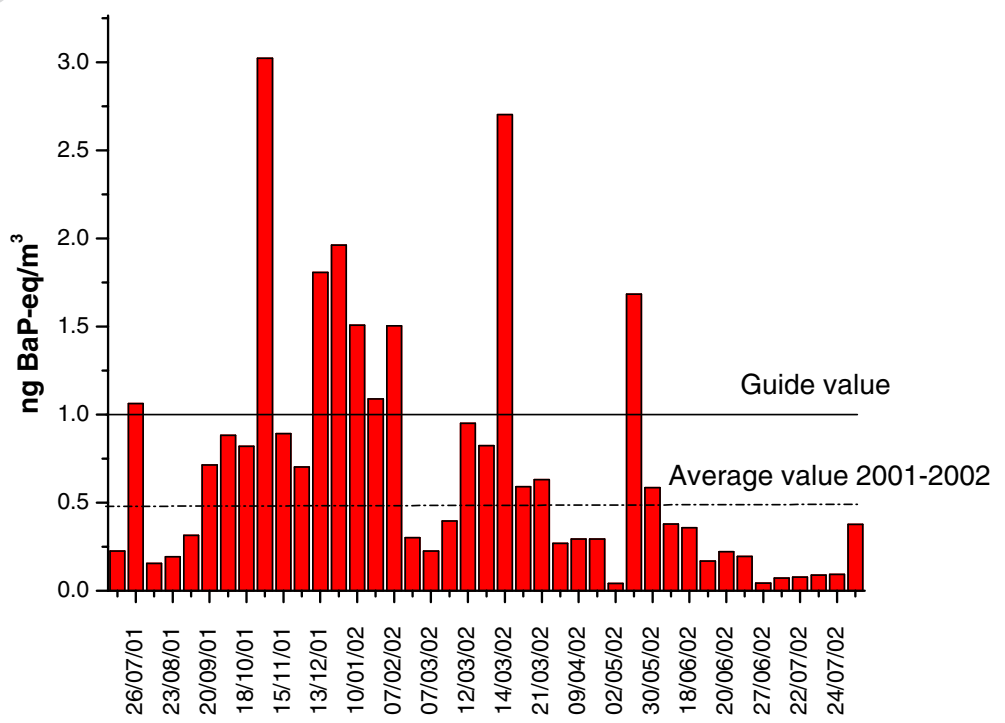


Water Air Soil Pollut

3943.2 Correlation of PAH with Meteorological Variables

395 In this section, the possible influence of the local 396 meteorological variables during the sampling dates on 397 the total and individual PAH concentration was carried 398 out by using statistical tools.

399 The Pearson correlation coefficients between the 400 total of PAH, the PM10, the individual PAH (Phe, An, 401 2+2/4MePhe, 9MePhe, 1MePhe, Dimephe, Fth, Py, $402 \mathrm{BaA}$, Chry, BbF, BkF, BeP, BaP, IcdP, BghiP and Co) 403 and the meteorological parameters including rainfall, 404 temperature, humidity, radiation, wind velocity and 405 wind direction (Table 2) were calculated.

406 It is observed that with regard to the temperature, 407 the most volatile PAH, Phe, An, 2+2/4Mephe, 408 9Mephe, 1Mephe, Dimephe, Fth and Py did not show 409 correlation with the temperature indicating that these 410 PAH did not show seasonal behaviour. This indicated 411 that the pollution sources producing these compounds 412 were mainly not seasonal. On the other hand,, a sig413 nificant negative correlation was observed for $\mathrm{BaA}$, 414 Chry, BbF, BkF, BeP, BaP, IcdP + DahA, BghiP and 415 Co with the temperature indicating that these $\mathrm{PAH}$ 416 showed seasonality, it means the pollution sources, 417 which produced these pollutants were seasonal. Sev418 eral studies have indicated the seasonal behaviour of 419 atmospheric PAH (Barrero Mazquiarán and Cantón 420 Ortiz de Pinedo 2007; Dimashki et al. 2001; Mastral 421 et al. 2003). Seasonal activities such as the use of 422 fossil fuels for heating in winter, and pho-decay 423 reactions of ambient PAH in the summer are believed 424 to be the main causes of seasonal variations. How425 ever, the total PAH did not show any significant 426 negative correlation with the temperature indicating 427 that the major sources of PAH were no seasonal. Traffic 428 and industry have been associated to no seasonal sources 429 although from these correlations nothing could be 430 deduced with regard to which pollution sources were.

431 A significant positive correlation was found be432 tween the PM10 and the average temperature, 433 favouring the high temperatures the accumulation of 434 particulate matter. Van der Wal and Janssen (2000) 435 also confirmed this correlation during summer under 436 the conditions of high temperatures and dry weather.

437 A positive significant correlation at the level of $43899 \%$ was found between the total of PAH and the 439 relative humidity. This positive correlation was also 440 found in a previous article published by these authors 441 (Mastral et al. 2003) and could be due to a deposi- tional effect of the PAH in gas phase as consequence of the environmental humidity (Dickhut and Gustafson 1997). Harrison et al. (1996) also showed that combustion sources such as vehicular, incineration, coal and metalliferous processes were positively correlated with relative humidity. BaA, Chry, BbF, BkF, BeP, $\mathrm{BaP}$, IcdP+DahA, BghiP and Co also showed a positive correlation with the relative humidity.

A significant negative correlation was found between the total of PAH and the radiation, the wind direction and the wind speed. Regarding the solar radiation, this parameter is implicated in the degradation of reactive PAH on particles decreasing the total of PAH especially in seasons with more solar radiation. Concerning the wind speed and wind direction, the negative correlation with the total of PAH shows the influence of local sources as pollution sources (Karar and Gupta 2006). Both parameters play an important role in dispersing contaminants with the accumulation of particles during low wind periods and less degrees in the wind direction $(\mathrm{N}, \mathrm{NE}$, E) and the removal during strong winds and more degrees in the wind direction (W, NW). For the individual $\mathrm{PAH}$, it was observed that the volatile PAH, Phe An, 2+2/4Mephe, 9Mephe, 1Mephe and Dimephe were the compounds more affected by the wind speed. It means that volatile PAH were more probably swept by strong winds. Regarding the wind direction, most of the individual PAH showed a significant negative correlation with the wind direction. The higher the degrees in the wind direction, the lower the PAH concentrations showing the prevalence of local pollution sources coming from the N, NE and $\mathrm{E}$ direction, direction in which most of the industrial parks were located. These negative correlations were also found between the PM10 and the wind speed (Karar and Gupta 2006) and the wind direction.

Considering the localization of Zaragoza, in Ebro valley and affected by a special kind of wind, "cierzo" (NW direction), coming from the Moncayo Mountain, it was also interesting to represent the mean total PAH concentrations with the wind direction (Fig. 4) in order to know which wind direction showed the highest PAH concentrations and to which source it could be attributed. It is observed that the highest PAH concentrations were obtained in the NE and SE direction. Taking into account the localization of the sampling place, according to Fig. 1, the NE and SE directions correspond to different industrial parks and paper 
Table 2 Pearson correlation coefficients between the individual PAH, the total PAH, the PM10 and the meteorological variables (rainfall, temperature, relative humidity, irradiation, wind velocity and wind direction)

\begin{tabular}{|c|c|c|c|c|c|c|c|c|c|c|c|c|}
\hline & $\mathrm{Ph}$ & An & MePhe24 & MePhe9 & MePhe1 & Dimephe & Fth & Py & $\mathrm{BaA}$ & Chry & $\mathrm{BbF}$ & $\mathrm{BkF}$ \\
\hline $\mathrm{Ph}$ & 1 & & & & & & & & & & & \\
\hline An & $0.925^{\mathrm{a}}$ & 1 & & & & & & & & & & \\
\hline MePhe24 & $0.963^{\mathrm{a}}$ & $0.882^{\mathrm{a}}$ & 1 & & & & & & & & & \\
\hline MePhe9 & $0.933^{\mathrm{a}}$ & $0.908^{\mathrm{a}}$ & $0.931^{\mathrm{a}}$ & 1 & & & & & & & & \\
\hline MePhe1 & $0.945^{\mathrm{a}}$ & $0.957^{\mathrm{a}}$ & $0.916^{\mathrm{a}}$ & $0.956^{\mathrm{a}}$ & 1 & & & & & & & \\
\hline Dimephe & $0.807^{\mathrm{a}}$ & $0.886^{\mathrm{a}}$ & $0.726^{\mathrm{a}}$ & $0.866^{\mathrm{a}}$ & $0.913^{\mathrm{a}}$ & 1 & & & & & & \\
\hline Fth & $0.894^{\mathrm{a}}$ & $0.803^{\mathrm{a}}$ & $0.879^{\mathrm{a}}$ & $0.860^{\mathrm{a}}$ & $0.843^{\mathrm{a}}$ & $0.764^{\mathrm{a}}$ & 1 & & & & & \\
\hline Py & $0.898^{\mathrm{a}}$ & $0.805^{\mathrm{a}}$ & $0.892^{\mathrm{a}}$ & $0.893^{\mathrm{a}}$ & $0.842^{\mathrm{a}}$ & $0.748^{\mathrm{a}}$ & $0.974^{\mathrm{a}}$ & 1 & & & & \\
\hline $\mathrm{BaA}$ & 0.124 & 0.123 & 0.138 & 0.172 & 0.164 & 0.213 & 0.228 & 0.204 & 1 & & & \\
\hline Chry & 0.248 & $0.328^{\mathrm{b}}$ & 0.238 & 0.296 & $0.322^{\mathrm{b}}$ & $0.402^{\mathrm{a}}$ & $0.372^{\mathrm{b}}$ & $0.345^{\mathrm{b}}$ & $0.908^{\mathrm{a}}$ & 1 & & \\
\hline $\mathrm{BbF}$ & 0.061 & 0.212 & 0.084 & 0.097 & 0.129 & 0.172 & 0.223 & 0.189 & $0.680^{\mathrm{a}}$ & $0.780^{\mathrm{a}}$ & 1 & \\
\hline $\mathrm{BkF}$ & -0.091 & 0.008 & -0.049 & -0.053 & -0.020 & 0.015 & 0.086 & 0.051 & $0.746^{\mathrm{a}}$ & $0.760^{\mathrm{a}}$ & $0.939^{\mathrm{a}}$ & 1 \\
\hline $\mathrm{BeP}$ & 0.131 & 0.296 & 0.136 & 0.204 & 0.251 & $0.342^{\mathrm{b}}$ & 0.295 & 0.263 & $0.672^{\mathrm{a}}$ & $0.813^{\mathrm{a}}$ & $0.952^{\mathrm{a}}$ & $0.905^{\mathrm{a}}$ \\
\hline $\mathrm{BaP}$ & -0.048 & 0.030 & 0.007 & 0.009 & 0.039 & 0.064 & 0.150 & 0.124 & $0.731^{\mathrm{a}}$ & $0.768^{\mathrm{a}}$ & $0.892^{\mathrm{a}}$ & $0.962^{\mathrm{a}}$ \\
\hline IcdP + DahA & 0.179 & 0.151 & 0.302 & 0.298 & 0.260 & 0.174 & 0.305 & 0.273 & $0.701^{\mathrm{a}}$ & $0.628^{\mathrm{a}}$ & $0.438^{\mathrm{a}}$ & $0.536^{\mathrm{a}}$ \\
\hline BghiP & 0.243 & 0.265 & $0.375^{\mathrm{b}}$ & $0.354^{\mathrm{b}}$ & $0.315^{\mathrm{b}}$ & 0.233 & $0.423^{\mathrm{a}}$ & $0.413^{\mathrm{a}}$ & $0.577^{\mathrm{a}}$ & $0.640^{\mathrm{a}}$ & $0.515^{\mathrm{a}}$ & $0.538^{\mathrm{a}}$ \\
\hline $\mathrm{Co}$ & 0.265 & $0.327^{\mathrm{b}}$ & $0.428^{\mathrm{a}}$ & $0.415^{\mathrm{a}}$ & $0.375^{\mathrm{b}}$ & 0.230 & $0.377^{\mathrm{b}}$ & $0.380^{\mathrm{b}}$ & $0.388^{b}$ & $0.450^{\mathrm{a}}$ & $0.431^{\mathrm{a}}$ & $0.420^{\mathrm{a}}$ \\
\hline Total PAH & $0.583^{\mathrm{a}}$ & $0.611^{\mathrm{a}}$ & $0.635^{\mathrm{a}}$ & $0.650^{\mathrm{a}}$ & $0.643^{\mathrm{a}}$ & $0.591^{\mathrm{a}}$ & $0.718^{\mathrm{a}}$ & $0.699^{\mathrm{a}}$ & $0.720^{\mathrm{a}}$ & $0.824^{\mathrm{a}}$ & $0.703^{\mathrm{a}}$ & $0.648^{\mathrm{a}}$ \\
\hline PM10 & 0.083 & -0.018 & 0.133 & 0.064 & 0.024 & -0.035 & 0.072 & 0.074 & $0.337^{\mathrm{b}}$ & 0.220 & 0.218 & 0.303 \\
\hline Rainfall & 0.090 & 0.198 & 0.162 & 0.252 & 0.193 & 0.233 & 0.127 & 0.145 & 0.121 & 0.077 & -0.016 & -0.036 \\
\hline T average & 0.268 & 0.208 & 0.229 & 0.161 & 0.127 & 0.058 & 0.053 & 0.108 & $-0.315^{\mathrm{b}}$ & $-0.319^{\mathrm{b}}$ & $-0.312^{\mathrm{b}}$ & $-0.406^{\mathrm{a}}$ \\
\hline $\mathrm{R}$ humid & 0.028 & 0.135 & 0.060 & 0.182 & 0.218 & 0.282 & 0.113 & 0.114 & $0.433^{\mathrm{a}}$ & $0.496^{\mathrm{a}}$ & $0.439^{\mathrm{a}}$ & $0.482^{\mathrm{a}}$ \\
\hline Irradiation & 0.046 & -0.034 & -0.003 & -0.055 & -0.103 & -0.134 & -0.096 & -0.068 & $-0.394^{\mathrm{b}}$ & $-0.443^{\mathrm{a}}$ & $-0.372^{\mathrm{b}}$ & $-0.434^{\mathrm{a}}$ \\
\hline Wind speed & $-0.347^{b}$ & $-0.360^{\mathrm{b}}$ & $-0.383^{\mathrm{b}}$ & $-0.362^{\mathrm{b}}$ & $-0.372^{\mathrm{b}}$ & $-0.313^{b}$ & -0.286 & -0.298 & -0.143 & -0.209 & -0.249 & -0.198 \\
\hline Wind direction & $-0.349^{b}$ & $-0.410^{\mathrm{a}}$ & $-0.428^{\mathrm{a}}$ & $-0.461^{\mathrm{a}}$ & $-0.425^{\mathrm{a}}$ & $-0.408^{\mathrm{a}}$ & -0.291 & $-0.363^{\mathrm{b}}$ & $-0.409^{\mathrm{a}}$ & $-0.458^{\mathrm{a}}$ & $-0.368^{\mathrm{b}}$ & -0.302 \\
\hline
\end{tabular}

${ }^{\text {a }}$ Correlation is significant at the 0.01 level (two-tailed).

${ }^{\mathrm{b}}$ Correlation is significant at the 0.05 level (two-tailed).

491 industries close to the sampling place, suggesting in492 fluence from the several industrial activities taking 493 place in the area. At high scale, this NE direction cor494 responds to Catalonia, a very industrialized area, from 495 which pollutants could be coming as a function of the 496 meteorological variables. The $\mathrm{S}$ direction also showed 497 contribution to the total of PAH and was mainly 498 associated to a highway very close to the sampling 499 place and located in this direction.

500 The NW direction was the prevailing wind direc501 tion, with a $36 \%$ of frequency and with low con502 centration of PAH. Precisely, this NW direction is 503 associated to the cierzo wind, which predominates in 504 Zaragoza city. In fact, the average wind speed for the $505 \mathrm{NW}$ direction was $4 \mathrm{~m} / \mathrm{s}$ reaching values until $8 \mathrm{~m} / \mathrm{s}$. 506 The low PAH concentrations showed at this direction 507 seem to indicate the important role that cierzo per508 forms in Zaragoza regarding pollution transport 509 (Mastral et al. 2003). In this way, the cierzo acts like 510 sweeping the pollutants, avoiding in this case the 511 possible pollution, which could be originated and 512 accumulated in Zaragoza due to its location in the
Ebro valley. On the other hand, the directions 513 associated to high PAH concentrations, NE and SE directions, where the main industrial activities were located in Zaragoza, showed a frequency of $2 \%$ and $15 \%$, respectively with calm conditions and average wind speeds of 0.4 and $1.7 \mathrm{~m} / \mathrm{s}$, which prevented the dispersion of pollutants. The $\mathrm{S}$ direction also prevented this dispersion showing a frequency of $10 \%$ with low average wind speed of $1.8 \mathrm{~m} / \mathrm{s}$.

\subsection{Principal Component Analysis}

Principal Component Analysis (PCA) was used in this work as a tool, in order to identify the main pollution sources in the atmosphere and to statistically select source fingerprints. PCA with Varimax rotation was applied to the data corresponding to each individual $\mathrm{PAH}$ and three factors were obtained explaining $89.8 \%$ of the total variance (Table 3 ).

The first factor, PC1 explained $50.6 \%$ of the variance with high loadings $(>0.85)$ for Phe, An, DiMePhe, 2+2/4MePhe, $1 \mathrm{MePhe,} 9 \mathrm{MePhe,} \mathrm{Fth} \mathrm{and}$ 523 
Water Air Soil Pollut

\begin{tabular}{|c|c|c|c|c|c|c|c|c|c|c|c|c|c|}
\hline $\mathrm{BeP}$ & $\mathrm{BaP}$ & $\begin{array}{r}\mathrm{IcdP}+ \\
\text { DahA }\end{array}$ & BghiP & Co & Total PAH & PM10 & Rainfall & $\mathrm{T}$ average & $\mathrm{R}$ humid & Irradiation & $\begin{array}{l}\text { Wind } \\
\text { speed }\end{array}$ & $\begin{array}{l}\text { Wind } \\
\text { direction }\end{array}$ & $\mathrm{t} 2.2$ \\
\hline & & & & & & & & & & & & & $\begin{array}{l}\mathrm{t} 2.3 \\
\mathrm{t} 2.4 \\
\mathrm{t} 2.5 \\
\mathrm{t} 2.6 \\
\mathrm{t} 2.7 \\
\mathrm{t} 2.8 \\
\mathrm{t} 2.9 \\
\mathrm{t} 2.10 \\
\mathrm{t} 2.11 \\
\mathrm{t} 2.12 \\
\mathrm{t} 2.13 \\
\mathrm{t} 2.14\end{array}$ \\
\hline 1 & & & & & & & & & & & & & $\mathrm{t} 2.15$ \\
\hline $0.910^{\mathrm{a}}$ & 1 & & & & & & & & & & & & $\mathrm{t} 2.16$ \\
\hline $0.449^{\mathrm{a}}$ & $0.586^{\mathrm{a}}$ & 1 & & & & & & & & & & & $\mathrm{t} 2.17$ \\
\hline $0.549^{\mathrm{a}}$ & $0.632^{\mathrm{a}}$ & $0.879^{\mathrm{a}}$ & 1 & & & & & & & & & & $\mathrm{t} 2.18$ \\
\hline $0.446^{\mathrm{a}}$ & $0.505^{\mathrm{a}}$ & $0.782^{\mathrm{a}}$ & $0.895^{\mathrm{a}}$ & 1 & & & & & & & & & $\mathrm{t} 2.19$ \\
\hline $0.753^{\mathrm{a}}$ & $0.701^{\mathrm{a}}$ & $0.753^{\mathrm{a}}$ & $0.826^{\mathrm{a}}$ & $0.740^{\mathrm{a}}$ & 1 & & & & & & & & $\mathrm{t} 2.20$ \\
\hline 0.162 & 0.277 & 0.247 & 0.103 & 0.062 & 0.211 & 1 & & & & & & & $\mathrm{t} 2.21$ \\
\hline 0.041 & -0.023 & $0.361^{b}$ & $0.423^{\mathrm{a}}$ & $0.431^{\mathrm{a}}$ & 0.247 & -0.025 & 1 & & & & & & $\mathrm{t} 2.22$ \\
\hline$-0.377^{\mathrm{b}}$ & $-0.503^{\mathrm{a}}$ & $-0.470^{\mathrm{a}}$ & $-0.488^{\mathrm{a}}$ & $-0.398^{\mathrm{a}}$ & -0.295 & $0.342^{\mathrm{b}}$ & -0.131 & 1 & & & & & $\mathrm{t} 2.23$ \\
\hline $0.551^{\mathrm{a}}$ & $0.592^{\mathrm{a}}$ & $0.467^{\mathrm{a}}$ & $0.512^{\mathrm{a}}$ & $0.470^{\mathrm{a}}$ & $0.498^{\mathrm{a}}$ & 0.098 & 0.264 & $-0.641^{\mathrm{a}}$ & 1 & & & & $\mathrm{t} 2.24$ \\
\hline$-0.456^{\mathrm{a}}$ & $-0.541^{\mathrm{a}}$ & $-0.575^{\mathrm{a}}$ & $-0.615^{\mathrm{a}}$ & $-0.502^{\mathrm{a}}$ & $-0.467^{\mathrm{a}}$ & 0.173 & -0.273 & $0.836^{\mathrm{a}}$ & $-0.794^{\mathrm{a}}$ & 1 & & & $\mathrm{t} 2.25$ \\
\hline-0.278 & -0.254 & -0.175 & -0.217 & -0.242 & $-0.349^{\mathrm{b}}$ & $-0.553^{\mathrm{a}}$ & -0.051 & -0.216 & -0.304 & 0.097 & 1 & & $\mathrm{t} 2.26$ \\
\hline$-0.423^{\mathrm{a}}$ & $-0.345^{\mathrm{b}}$ & -0.303 & $-0.356^{\mathrm{b}}$ & $-0.337^{\mathrm{b}}$ & $-0.506^{\mathrm{a}}$ & $-0.435^{\mathrm{a}}$ & -0.243 & -0.120 & $-0.436^{\mathrm{a}}$ & 0.137 & $0.581^{\mathrm{a}}$ & 1 & $\mathrm{t} 2.27$ \\
\hline
\end{tabular}

533 Py. According to bibliography, emissions from coal 534 combustion exhibit higher relative amounts of alkyl 535 PAH than other combustion sources (Lee et al. 1977; 536 Simo et al. 1997; Simcik et al. 1999). This first factor 537 is also highly loaded on Phe, Fth, Py and An, all of 538 which are predominant in coal combustion signals 539 (Harrison et al. 1996; Masclet et al. 1987). Diesel 540 emissions also produce relatively high concentrations 541 of alkyl PAH (Nielsen 1996). However, Factor 1 lacks 542 any significant loading on IcdP, another tracer of 543 diesel emissions (Li et al. 1993).

544 Other authors like Park et al. (2002) related the 545 presence of Phe, Fth, Py and An with the industrial 546 combustion of oil, incineration and biomass burning. 547 Khalili et al. (1995) and Duval and Friedlander (1981) 548 identified these four $\mathrm{PAH}$ as tracers for wood 549 combustion sources.

550 In this way, Factor 1 was selected to represent a 551 mixture of sources related to stationary sources 552 including combustion of fossil fuels and/or biomass 553 for generating power and industrial activities. On the 554 one hand, the combustion of fossil fuels is used in 555 power generation and iron and steel processes. In addition, the paper fabrics and water treatments systems would also be represented on this factor as they burn biomass, residues and mud to produce the necessary heat in the process. Therefore, the contribution of different types of industries existing in the sampling area is reflected on this factor and it was considered as the dominant pollution source in the sampled area.

Considering this factor as representative of pollution sources related to industry and because these PAH did not show correlation with the temperature, as mentioned in Section 3.2, this indicated that industries were a no seasonal pollution source in Zaragoza.

The second factor, PC2 explained $30.9 \%$ of the variance with high loadings for $\mathrm{BaA}, \mathrm{Chry}, \mathrm{BbF}, \mathrm{BkF}$, $\mathrm{BeP}$ and $\mathrm{BaP}$. This factor was related to $\mathrm{PAH}$ with four and five aromatic rings.

Previous studies have reported that BaA, Chry, $\mathrm{BbF}, \mathrm{BkF}, \mathrm{BaP}$ and DahA are compounds originated mainly from vehicular emissions (Dallarosa et al. 2005b). In particular, $\mathrm{BaP}$ and $\mathrm{BaA}$ are important tracers in gasoline and diesel emissions (Harkov and Greenberg 1985; Daisey et al. 1979). With regard to 


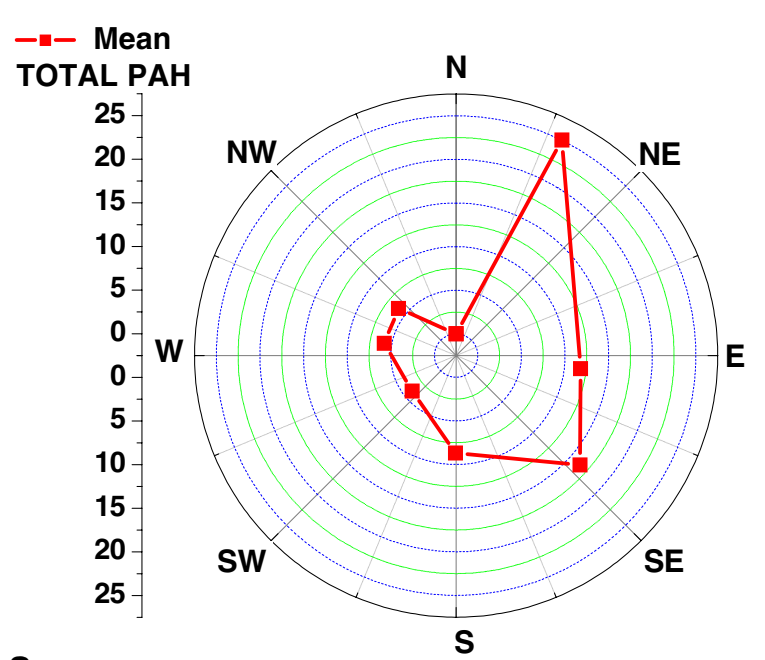

a

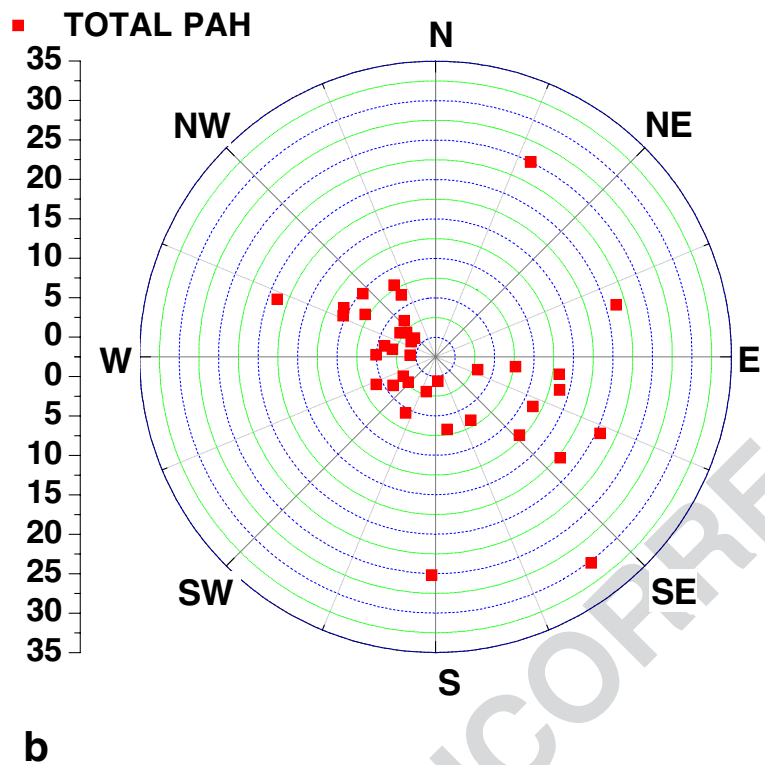

Fig. 4 Distribution of a the mean total PAH concentrations $\left(\mathrm{ng} / \mathrm{m}^{3}\right)$ and $\mathbf{b}$ the $\mathrm{PAH}$ concentration for each sampling date $\left(\mathrm{ng} / \mathrm{m}^{3}\right)$ with the wind direction

$579 \mathrm{BeP}$, this compound indicated contribution from 580 oil burning (Mantis et al. 2005). Rogge et al. 581 (1993) identified BeP and benzofluoranthenes like 582 prevalent $\mathrm{PAH}$ in particle-phase natural gas home 583 heating emissions.

584 According to this, Factor 2 could be mainly at585 tributed to motor vehicles emissions, without distin586 guishing between diesel and gasoline emissions and 587 with the contribution of natural gas home heating. 588 Considering the sampling point, it is reflected on the 589 one hand, the proximity of a highway in addition to the city traffic, and on the other hand, because it is a residential area where gas natural is used as residential heating, the domestic heating as PAH pollution source.

The third factor, PC3 explained $8 \%$ of the variance with high loadings for IcdP, BghiP and Co, PAH with 6 and 7 aromatic rings. This factor can be mainly attributed to vehicle emissions because BghiP is considered as a typical molecular marker of vehicle emission (Harrison et al. 1996; Daisey et al. 1986) and also IcdP (Kulkarni et al. 2000) and Co (Venkataraman and Friedlander 1994). Therefore, this factor was selected to represent vehicular emissions and it showed the importance of the local pollution sources in Zaragoza, mainly due to the presence of the highway.

Taking into account the information obtained with the PCA and the one obtained with the meteorological variables, in particular with the temperature, it could be deduced that residential heating was a seasonal pollution source, as the PAH representing these factors were negatively correlated to temperature. The cold

Table 3 Principal component analysis obtained with rotation method, Varimax with Kaiser normalization, applied to the individual PAH compounds concentrations

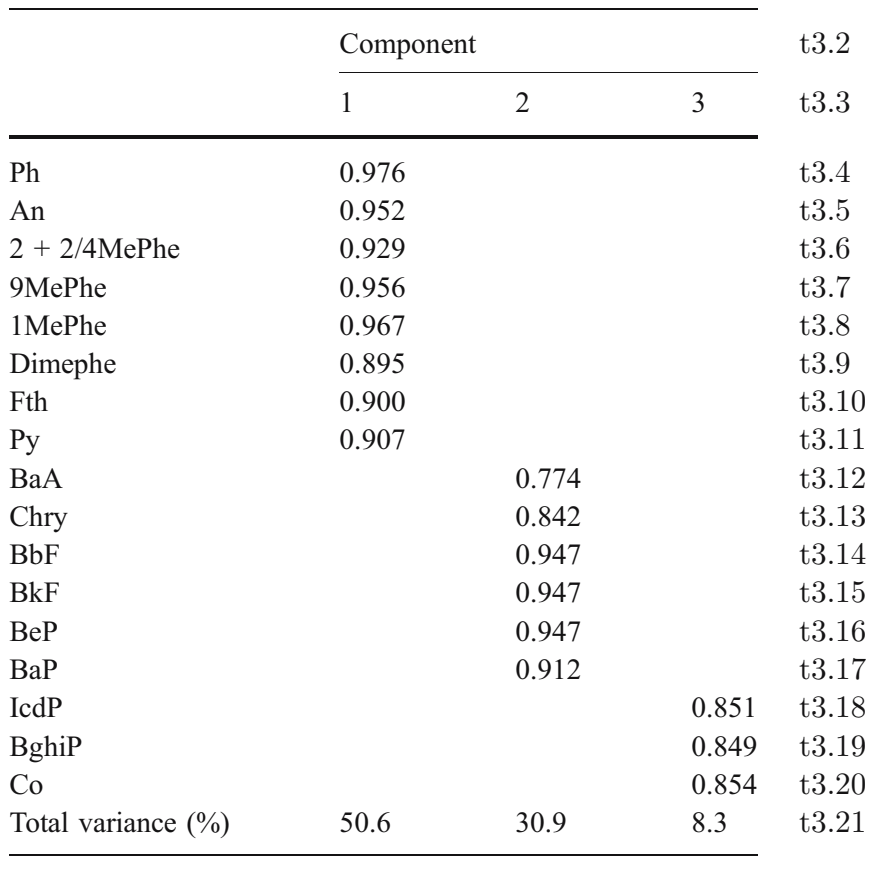

Only factors loading higher than 0.7 were considered. t3.1

3.2 
Water Air Soil Pollut

t4.1 Table 4 Average total PAH concentration, frequency and average PM10 concentration as a function of the air masses origin according to the backward air trajectories, TOMs aerosol index maps, SeaWiFS satellite images and synoptic charts of pressure at sea level

\begin{tabular}{lllll}
\cline { 2 - 4 } t4.2 & $\begin{array}{l}\text { Scenario } \\
\text { type }\end{array}$ & $\begin{array}{l}\text { Average total } \\
\text { PAH ng/m } / \mathrm{m}^{3}\end{array}$ & $\begin{array}{l}\text { Frequency }(\%) \\
n=41\end{array}$ & $\begin{array}{l}\text { Average } \\
\text { PM10 } \mu \mathrm{g} / \mathrm{m}^{3}\end{array}$ \\
\cline { 2 - 5 } t4.3 & REG & 25.4 & 17.1 & 50.3 \\
t4.4 & MED & 9.7 & 7.3 & 43.2 \\
t4.5 & EUR & 14.6 & 7.3 & 42.9 \\
t4.6 & AW & 8.1 & 2.4 & 51.9 \\
t4.7 & ASW & 7.4 & 2.4 & 24.6 \\
t4.8 & ANW & 9.6 & 12.2 & 27.0 \\
t4.9 & AN & 7.9 & 12.2 & 30.6 \\
t4.10 AFR & 7.4 & 39.0 & 48.9
\end{tabular}

t4.11 REG Regional corresponding to the Iberian Peninsula, MED Mediterranean, EUR Europe, $A W$ Atlantic West, $A S W$ Southwest Atlantic, $A N W$ Northwest Atlantic, $A N$ North Atlantic, and $A F R$ North Africa (Salvador 2004).

612 weather in Zaragoza would also influence on vehicle 613 increase and city traffic emissions could undergo a 614 possible seasonal behaviour in Zaragoza.

\section{3.4 Long-Range Transport and Local Sources}

616 In order to determine the influence of transport over 617 the PAH concentration, it was calculated the average 618 total PAH concentrations as a function of the origin of 619 air masses considering as possible sectors the ones 620 established by Salvador (2004) (Table 4) and taking 621 into account the $120 \mathrm{~h}$ backward air trajectories of 622 each sampling date performed at 9:00 a.m., arriving at 623100,500 and $1,000 \mathrm{~m}$ above sea level, the TOMS 624 aerosol index maps, the SeaWiFS satellite images and 625 the synoptic charts of pressure at sea level. The frequency of each scenario type and the average PM10 concentration were also shown in Table 4.

The highest PAH concentrations were obtained under regional recirculation scenarios favouring pollutant accumulation. Also high PAH concentrations were obtained when air masses were coming from the Central and Oriental Europe. These areas corresponded to very industrialized areas. The lowest PAH concentrations corresponded to air masses coming from the Atlantic and North Africa.

The more detected scenario for the dates sampled in Zaragoza was the long-range transport from North Africa with a frequency of $39 \%$ followed by regional scenarios which predominated in the $17 \%$ of the dates. It was observed that the main processes of natural and anthropogenic origin influencing on the particulate matter levels were: advection processes of West Atlantic air, circulations of air masses at regional level, intrusions of African air masses and advections of air masses coming from the Mediterranean Sea and Europe. While the natural ones were related to low PAH concentrations, the ones with anthropogenic origin reflected higher PAH concentrations.

It was also interesting to study the ageing air mass through the photochemical degradation in order to know whether the local pollution sources or the longrange transport influenced on the pollutant levels. $\mathrm{BaA}$ and $\mathrm{BaP}$ degrade in the atmosphere more easily than their isomers Chry and $\mathrm{BeP}$ due to their higher reactivity during transportation. Gogou et al. (1996) and Tolosa et al. (1996) showed in Mediterranean aerosols that the concentrations of these compounds decreased during their transport from urban areas to other more isolated. This could be used to assess the impact of local sources against long-range transport over the PAH concentrations. In this way, BaA/Chry
626

627

628

629

630

631

632

633

634

635

636

637

638

639

640

641

642

643

644

645

646

647

648

649

650

651

652

653

654

655

656

657

658

659

660

661
Table $5 \mathrm{BaP}\left(\mathrm{ng} / \mathrm{m}^{3}\right)$, total $\mathrm{PAH}\left(\mathrm{ng} / \mathrm{m}^{3}\right)$, ratios $\mathrm{BaA} /$ Chry and $\mathrm{BaP} / \mathrm{BeP}$, air mass origins and PM10 for the dates exceeding $1 \mathrm{ng} / \mathrm{m}^{3}$ of BaP-eq

\begin{tabular}{llllllll}
\hline & BaP eq & BaP & Total PAH & BaA/Chry & BaP/BeP & Scenario type & PM10 \\
\hline $26 / 07 / 2001$ & 1.1 & 0.4 & 30 & 0.6 & 0.6 & REG & 57.4 \\
$30 / 10 / 2001$ & 3.0 & 2.1 & 26 & 1.0 & 1.0 & AFR & 104.3 \\
$13 / 12 / 2001$ & 1.8 & 1.3 & 16 & 0.6 & 0.9 & EUR & 59.6 \\
$27 / 12 / 2001$ & 2.0 & 1.4 & 20 & 0.7 & 1.3 & AN & 42.7 \\
$10 / 01 / 2002$ & 1.5 & 1.2 & 15 & 0.8 & 1.4 & MED & 51.7 \\
$24 / 01 / 2002$ & 1.1 & 0.7 & 11 & 1.1 & 1.1 & ANW & 34.0 \\
$07 / 02 / 2002$ & 1.5 & 0.9 & 19 & 0.8 & 1.1 & ANW & 23.0 \\
$14 / 03 / 2002$ & 2.7 & 1.9 & 25 & 0.9 & 0.7 & ASW & 24.6 \\
$16 / 05 / 2002$ & 1.7 & 1.3 & 11 & 0.9 & 0.9 & AFR & 53.1 \\
\hline
\end{tabular}

$\mathrm{t} 5.1$

$\mathrm{t} 5.2$

$\mathrm{t} 5.3$

$\mathrm{t} 5.4$

$\mathrm{t} 5.5$

$\mathrm{t} 5.6$

t5.7

t5.8

t5.9

$\mathrm{t} 5.10$ 
662 and $\mathrm{BaP} / \mathrm{BeP}$ close to 1 would indicate negligible 663 photochemical degradation and major impact from 664 local emission sources. Lower ratios would indicate 665 more aged PAH.

666 In this work, both ratios showed average values of 6670.74 and 0.95 indicating that the air masses were 668 relatively fresh and not aged. The Pearson correlation 669 values were significant at $99 \%$ level (0.91in both 670 cases) indicating that both compounds of each one 671 were originated by the same sources. The correlation 672 between both ratios was significant at $99 \%$ level with 673 a Pearson coefficient of 0.5 showing that these 674 compounds might share a similar transport pathway 675 (Ding et al. 1997).

676 The seasonal values of $\mathrm{BaA} / \mathrm{Chry}$ and $\mathrm{BaP} / \mathrm{BeP}$ for 677 the sampling dates were also calculated with mean 678 values of 0.81 and 1.1 for the cold season and 0.68 679 and 0.86 for the warm season. No significant seasonal 680 variations were obtained showing the influence of 681 local emission sources during all the year.

\section{3.5 Episodes of High PAH Concentration}

683 Table 5 shows the dates in which the value of $1 \mathrm{ng} / \mathrm{m}^{3}$ 684 for the BaP-eq was exceeded and also the scenario 685 type by considering the air mass origin interpreted 686 with the backward air trajectories, the TOMS aerosol 687 index maps, the SeaWiFS satellite images and the 688 synoptic charts of pressure at sea level. Only two of 689 these episodes took place during warm season and the rest during cold period in which pollutant dispersion and photochemical degradation were lower due to the lower sun radiation and mixture layer height.

For each sampling date, the contribution percentage of each PC obtained by principal component analysis was represented (Fig. 5). It is remarkable that for the dates with high BaP-eq concentrations the PC2 and PC3 contributions, identified with vehicular emissions and residential heating, mainly associated to local pollution sources, were majority.

In general, the ratios $\mathrm{BaA} / \mathrm{Chry}$ and $\mathrm{BaP} / \mathrm{BeP}$ are quite high, showing that air masses are relatively fresh and there is no significative photochemical degradation. In these cases, the high BaP-eq concentration would be due to local sources typical from urban areas. Nevertheless, for some dates there is evidence of long-range transport. This is the case of 13/12/ 2001. This date, classified as European according to the air mass origin, was considered as episode of high PM10 concentration. The photochemical tracer ratios, $\mathrm{BaA} / \mathrm{Cr}=0.62$ and $\mathrm{BaP} / \mathrm{BeP}=0.92$ seem to indicate that while for more volatile $\mathrm{PAH}$ there was photochemical degradation during their transport from Europe, the heavy PAH were mainly emitted from local pollution sources.

The 26/07/2001 was classified as regional recirculation episode with high PM10 concentration. Although the $\mathrm{BaP}$ concentration was not very high $\left(0.30 \mathrm{ng} / \mathrm{m}^{3}\right)$, the BaP-eq concentration was higher than $1 \mathrm{ng} / \mathrm{m}^{3}$. The $\mathrm{BaA} / \mathrm{Chry}=0.67$ and $\mathrm{BaP} / \mathrm{BeP}=$
690

691

692

693
Fig. 5 Percentage of each PC obtained by principal component analysis for each sampling date. The shown dates correspond to exceedances in the BaP-eq concentration $\left(>1.0 \mathrm{ng} / \mathrm{m}^{3}\right)$

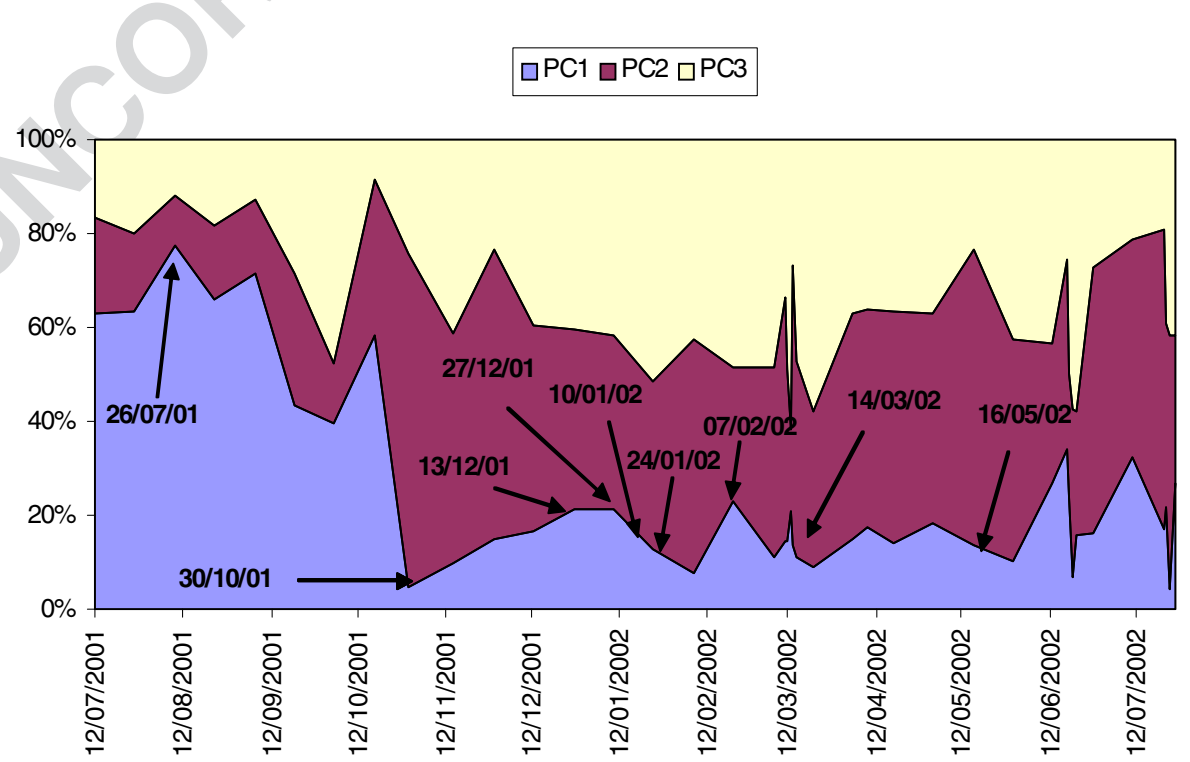


Water Air Soil Pollut

7200.64 indicated aged air masses during recirculation

721 and degradation due to the high solar radiation for this 722 date $\left(304.80 \mathrm{~W} / \mathrm{m}^{2}\right)$.

723 The dates corresponding to African scenarios, 30/ $72410 / 01$ and 16/05/02, where long-range transport pro725 cesses took place, showed no photochemical degrada726 tion according to the $\mathrm{BaA} /$ Chry and $\mathrm{BaP} / \mathrm{BeP}$ ratios. 727 This indicated the main contribution of local pollution 728 sources to PAH concentrations rather than the transport 729 of PAH on dust particles. However, these episodes of 730 African transport had a remarkable impact on the 731 particulate matter levels.

\section{Conclusions}

733 Despite Zaragoza city has got great advantages from 734 an air pollution point of view with regard to other 735 European cities because a predominant wind "cierzo" 736 sweeps pollutants, the limit value established by the 737 2004/107/EC Directive concerning PAH in air, $1 \mathrm{ng} / \mathrm{m}^{3}$ 738 of $\mathrm{BaP}$, is exceeded in $14.6 \%$ of the samples taken in 739 a yearly sampling during 2001-2002.

740 Taking into account other carcinogenic compounds 741 in addition to $\mathrm{BaP}, 22.5 \%$ of the samples showed 742 values of BaP-eq higher than $1 \mathrm{ng} / \mathrm{m}^{3}$.

743 Influence of the local meteorological variables on the 744 total PAH concentrations were explained and PCA 745 analysis showed that stationary sources related to 746 industry were the dominant pollution sources. Vehicular 747 emissions and natural gas home heating also signifi748 cantly contribute to the PAH levels in the sampled area.

749 The main PAH pollution sources were related to local 750 sources associated to regional air masses rather than 751 long-range transport. The influence of long-range 752 transport of anthropogenic origin also contributed to 753 PAH concentrations but for specific dates. The most 754 frequent scenarios, air masses coming from Africa with 755 natural origin, did not show high average PAH concen756 trations but high particulate matter levels.

759 Acknowledgments Authors would like to thank the Spanish 760 National Institute of Meteorology, for the Zaragoza meteoro761 logical data and the Government of Aragon (D.G.A. Spain) for 762 the grant to M.T. de la Cruz.

763 We also acknowledge the NASA for the Earth Probe TOMS 764 maps and satellite images; the NOAA Air Data Resources 765 Laboratory and the Australia's Bureau of Meteorology for the 766 HYSPLIT model, the synoptic charts of pressure and the FLN 767 meteorological data set.

\section{References}

Ambient Air Pollution by PAH. Position Paper, July 27th 2001. Prepared by the Working Group on PAH.

Barrero Mazquiarán, M. A., \& Cantón Ortiz de Pinedo, L. (2007). Organic composition of atmospheric urban aerosol: Variations and sources of aliphatic and polycyclic aromatic hydrocarbons. Atmospheric Research, 85(3-4), 288-299.

Borbély-Kiss, I., Kiss, A. Z., Koltay, E., Szabó, G., \& Bozó, L. (2004). Saharan dust episodes in Hungarian aerosol: Elemental signatures and transport trajectories. Aerosol Science, 35, 1205-1224.

Caricchia, A. M., Chiavarini, S., \& Pezza, M. (1999). Polycyclic aromatic hydrocarbons in the urban atmospheric particulate matter in the city of Naples (Italy). Atmospheric Environment, 33, 3731-3738.

Cecinato, A., Marino, F., Di Filippo, P., Lepore, L., \& Possanzini, M. (1999). Distribution of n-alkanes, PAH and nitrates-PAH between the fine and coarse fractions of inhalable atmospheric particulates. Journal of Chromatography, 846, 255-264.

Constantino, J. P., Redmond, C. K., \& Bearden, A. (1995). Occupationally related cancer risk among coke oven workers: 30 years of follow-up. Journal of Occupational and Environmental Medicine, 37, 597-604.

Daisey, J. M., Cheney, J. L., \& Lioy, P. J. (1986). Profiles of organic particulate emissions from air pollution sources: status and need for receptor source apportionment modelling. Journal of Air Pollution \& Control Association, 36, $17-33$.

Daisey, J. M., Leyko, M. A., \& Kneip, T. J. (1979). Polynuclear aromatic hydrocarbons. In: Ann Arbor Science Publishers, Ann Arbor, MI.

Dallarosa, J. B., Monego, J. G., Teixeira, E. C., Stefens, J. L., \& Wiegand, F. (2005b). PAH in atmospheric particles in the metropolitan area of Porto Alegre, Brazil. Atmospheric Environment, 39, 1609-1625.

Dallarosa, J. B., Teixeira, E. C., Pires, M., \& Fachel, J. (2005a). Study of the profile of PAHs in atmospheric particles PM10 using multivariate methods. Atmospheric Environment, 39, 6587-6596.

Dickhut, R. M., \& Gustafson, K. E. (1997). Particle/gas concentrations and distributions of PAHs in the atmosphere of southern Chesapeake Bay. Environmental Science\& Technology, 31(1), 140-147.

Dimashki, M., Lim, M. H., Harrison, R. M., \& Harrad, S. (2001). Temporal trends, temperature dependence and relative reactivity of atmospheric PAH. Environmental Science \& Technology, 35, 2264-2267.

Ding, X., Wang, X.-M., Xie, Z.-Q., Xiang, C.-H., Mai, B. X., Sun, L.-G., et al. (2007). Atmospheric PAH observed over the North Pacific Ocean and the Arctic area: Spatial distribution and source identification. Atmospheric Environment, 41, 2061-2072.

Directive 1999/30/EC of 22 April 1999 relating to limit values for sulphur dioxide, nitrogen dioxide and oxides of nitrogen, particulate matter and lead in ambient air. (1999), OJL 163, 29.6.1999, p.41. 
826 Directive 2004/107/EC of the European Parliament and of 827 the Council of 15 December 2004 relating to arsenic, 828 cadmium, mercury, nickel and PAH in ambient air.

829 Duval, M. M., \& Friedlander, S. K. (1981). Source resolution 830 of PAH in the Los Angeles atmosphere. Application of a $831 \quad$ CMB with first order decay. Technical Report No. EPA 832 600/2-81-161, US Government Printing Office, Washing833 ton DC, USA.

834 Gogou, A., Stratigakis, N., Kanakidou, M., \& Stephanou, E. G. 835 (1996). Organic aerosols in Eastern Mediterranean: com836 ponents source reconciliation by using molecular markers 837 and atmospheric back trajectories. Organic Geochemistry, $838 \quad 25,79-96$.

839 Gutiérrez-Dabán, A., Fernández-Espinosa, A. J., Ternero840 Rodríguez, M., \& Fernández-Alvarez, F. (2005). Particle 841 size distribution of PAH in urban air in southern 842 Spain. Analytical and Bioanalytical Chemistry, 381, 721843736

844 Halsall, C. J., Sweetman, A. J., Barrie, L. A., \& Jones, K. C. 845 (2001). Modeling the behavior of PAHs during atmo846 spheric transport from UK to the Artic. Atmospheric 847 Environment, 35, 255-267.

848 Harkov, R., \& Greenberg, A. (1985). BaP in New Hersey 849 results from a 27 site study. Journal of Air Pollution \& 850 Control Association, 35, 238-243.

851 Harrison, R. M., Smith, D. J. T., \& Luhana, L. (1996). Source 852 apportionment of atmospheric PAH collected from an urban 853 location in Birmingham, UK. Environmental Science \& 854 Technology, 30, 825-832.

855 HYSPLIT 4, (Hybrid Single-Particle Lagrangian Integrated 856 Trajectory) Model (1997). NOAA Air Resources Labora857 tory, Silver Spring, MD. from http:/www.arl.noaa.gov/ 858 ready/hysp_info.html.

859 Karar, K., \& Gupta, A. K. (2006). Seasonal variations and 860 chemical characterization of ambient PM10 at residencial 861 and industrial sites o fan urban region of Kolkata 862 (Calcuta), India. Atmospheric Research, (in press).

863 Khalili, N. R., Scheff, P. A., \& Holsen, T. M. (1995). PAH 864 source fingerprints for coke ovens, diesel and gasoline 865 engines, highway tunnels and wood combustion emis866 sions. Atmospheric Environment, 33, 4977-4986.

867 Larsen, J. C., \& Larsen, P. B. (1998). Chemical carcinogens. In 868 R. E. Hester, \& R. M. Harrison (Eds.) Air pollution and 869 health (pp. 33-56). Cambridge: The Royal Society of 870 Chemistry.

871 Lee, M. L., Prado, G. P., Howard, J. B., \& Hites, R. A. (1977). 872 873 874 875 876 Li, C. K., \& Kamens, R. M. (1993). The use of PAH as source 877 878 879 Lim, L. H., Harrison, R. M., \& Harrad, S. (1999). The contribution 880 of traffic to atmospheric concentrations of PAH. Environ881 mental Science \& Technology, 33, 3538-3542.

882 López, J. M., Callén, M. S., Murillo, R., García, T., Navarro, 883 M. V., de la Cruz, M. T., et al. (2005). Levels of selected 884 metals in ambient air PM10 in an urban site of Zaragoza 885 (Spain). Environmental Research, 99, 58-67.
Mantis, J., Chaloulakou, A., \& Samara, C. (2005). PM10bound PAH in the Greater Area of Athens, Greece. Chemosphere, 59, 593-604.

Marino, F., Cecinato, A., \& Siskos, P. (2000). Nitro-PAH in ambient particulate matter in the atmosphere of Athens. Chemosphere, 40, 533-537.

Masclet, P., Bresson, M. A., \& Mouvier, G. (1987). PAH emitted by power stations, and influence of combustion conditions. Fuel, 66, 556-562.

Mastral, A., \& Callén, M. S. (2000). A review on PAH emissions from energy generation. Environmental Science \& Technology, 34(15), 3051-3057.

Mastral, A., López, J. M., Callén, M. S., García, T., Murillo, T., \& Navarro, M. V. (2003). Spatial and temporal evolution of atmospheric PAH concentration in Zaragoza, Spain. Science of the Total Environment, 307, 111-124.

Nielsen, T. (1996). Traffic contribution of PAH in the centre of a large city. Atmospheric Environment, 20, 3481-90.

Park, S. S., Kim, Y. J., \& Kang, C. H. (2002). Atmospheric PAH in Seoul, Korea. Atmospheric Environment, 36, 2917-2924.

Pott, P. (1962). Chirurgical observations relative to the cataract, the polypus of the nose, the cancer of the scrotum, the different kinds of ruptures, and the mortification of the toes and feet. London, England, Hawes, Clark \& Collins, 1775, In: National Cancer Institute Monograph, 1962, pp $7-13$.

Prevedouros, K., Jones, K. C., \& Sweetman, A. J. (2004). Modeling the atmospheric fate and seasonality of polycyclic aromatic hydrocarbons in the UK. Chemosphere, 56, 195-208.

Rogge, W. F., Hildemann, L. M., Mazurek, M. A., Cass, G. R., \& Simoneit, B. R. T. (1993). Sources of fine organic aerosol:2. Non-catalyst and catalyst equipped automobiles and heavy duty diesel trucks. Environmental Science \& Technology, 27, 636-651.

Salvador, P. (2004). Caracterización de la contaminación atmosférica producida por partículas en suspensión en Madrid. Thesis, University of Madrid.

Schulte, A., Ernst, H., Peters, L., \& Heinrich, U. (1994). Induction of squamous-cell carcinomas in the mouse lung after long-term inhalation of PAH rich exhausts. Experimental and Toxicologic Pathology, 45(7), 415-421.

Simcik, M. F., Eisenreich, S. J., \& Lioy, P. J. (1999). Source apportionment and source/sink relationships of PAHs in the coastal atmosphere of Chicago and Lake Michigan. Atmospheric Environment, 33, 5071-5079.

Simo, R., Grimalt, J. O., \& Albaiges, J. (1997). Background levels of atmospheric hydrocarbons, sulphate and nitrate over the western Mediterranean. Environmental Science \& Technology, 31, 2697-2700.

Smith, D. J. T., Harrison, R. M., Luhana, L., Pio, C. A., Castro, L. M., Tariq, M. N., et al. (1996). Concentrations of particulate airborne PAH and metals collected in Lahore, Pakistan. Atmospheric Environment, 30(23), 4031-4040.

Tolosa, I., Bayona, J. M., \& Albaiges, J. (1996). Aliphatic and $\mathrm{PAH}$ and sulphur oxygen derivatives in northwestern Mediterranean sediments: Spatial and temporal variability, fluxes, budgets. Environmental Science \& Technology, 30, 2495-2503. 
Water Air Soil Pollut

946 Van der Wal, J. T., \& Janssen, L. H. J. M. (2000). Analysis of 947 spatial and temporal variation of PM10 concentrations in 948 the Netherlands using Kalman filtering. Atmospheric 949 Environment, 34, 3675-3687.

950 Venkataraman, C., \& Friedlander, S. K. (1994). Source 951 resolution of fine particulate $\mathrm{PAH}$ using a receptor model modified for reactivity. Journal of the Air \& Waste 952 Management Association, 44, 1103-1108.

Yassaa, N., Meklati, B. Y., Cecinato, A., \& Marino, F. (2001). 954 Particulate n-alkanes, n-alkanoic acids and PAH in the 955 atmosphere of Algiers City Area. Atmospheric Environment, 956 $35,1843-1851$. 


\section{AUTHOR QUERIES}

\section{AUTHOR PLEASE ANSWER ALL QUERIES.}

Q1. Li et al. (1993), Kulkarni et al. (2000) and Ding et al. (1997) were cited in the text but were not found in the reference list.

Q2. Please provide complete bibliographic information for Daisey et al. 1979 and Karar and Gupta 2006. 